\begin{tabular}{|c|c|c|}
\hline orts $i$ & \multicolumn{2}{|c|}{ Case Rep Gastroenterol 2014;8:67-71 } \\
\hline Gastroenterology & $\begin{array}{l}\text { DOI: 10.1159/000360843 } \\
\text { Publisned online: IVarch 8, } 2014\end{array}$ & $\begin{array}{l}\text { (c) } 2014 \text { S. Karger AG, Basel } \\
1662-0631 / 14 / 0081-0067 \$ 39.50 / 0 \\
\text { www.karger.com/crg }\end{array}$ \\
\hline & \multicolumn{2}{|c|}{$\begin{array}{l}\text { This is an Open Access article licensed under the terms of the Creative Common } \\
\text { Attribution-NonCommercial } 3.0 \text { Unported license (CC BY-NC) (www.karger.com/OA } \\
\text { license), applicable to the online version of the article only. Distribution permitted for non } \\
\text { commercial purposes only. }\end{array}$} \\
\hline
\end{tabular}

\title{
Abdominal Inflammatory Myofibroblastic Tumor
}

\author{
Roosmarijn L. Groenveld ${ }^{a} \quad$ Menno H. Raber ${ }^{a} \quad$ Richard Oosterhof-Berktas $^{b}$ \\ Erik Eijken $^{c}$ Joost M. Klaase ${ }^{a}$ \\ Departments of a Surgery and ${ }^{b}$ Radiology of Medisch Spectrum Twente, Enschede, \\ and ${ }^{\mathrm{C}}$ Department of Pathology, Laboratorium Pathologie Oost Nederland, Hengelo, \\ The Netherlands
}

\section{Key Words}

Abdominal inflammatory myofibroblastic tumor - Inflammatory myofibroblastic tumor . Inflammatory pseudotumor · Laparotomy

\begin{abstract}
A 28-year-old woman was referred to our hospital because of abdominal pain, weight loss and a palpable intra-abdominal mass. A CT scan revealed a tumor with a diameter of $7 \mathrm{~cm}$ with sharp margins, intra-tumoral fatty components and enhancing soft tissue. After initial workup, which suggested an inflammatory myofibroblastic tumor (IMT), she underwent laparotomy with complete resection. Pathological examination indeed revealed IMT. IMT is a rare benign neoplasm and has been described in nearly the entire body. It presents with nonspecific symptoms. The therapy of abdominal IMT consists of radical surgery because of high local recurrence rates. In this case report clinical, surgical, radiological and histological features with a review of the relevant literature are described.

(c) 2014 S. Karger AG, Basel
\end{abstract}

\section{Introduction}

Inflammatory myofibroblastic tumor (IMT), also known as inflammatory (myo)fibroblastic pseudotumor or inflammatory pseudotumor, is a rare benign neoplasm, often mistaken for malignancy or teratoma. The exact etiology of IMT is unknown, though it is suggested to occur secondary to infection, trauma or surgery. It can be located in the entire body and has a preference for children and young adults. The differential diagnosis consists of teratoma, liposarcoma and lymphoma. Up to date, therapy consists of radical surgery with 
Groenveld et al.: Abdominal Inflammatory Myofibroblastic Tumor

long-term follow-up. In this article we describe a case of abdominal IMT with clinical, surgical, radiological and histological features and present a review of the relevant literature.

\section{Case Report}

A 28-year-old woman was referred to our hospital because of abdominal pain and weight loss. During 4 weeks she had lost $15 \mathrm{~kg}$ in weight because of postprandial pain. She had pre-existent constipation, but no rectal bleeding, nor did she experience any night sweating. Physical examination did not show any anomalies except a left paraumbilical palpable mass. Ultrasound revealed a 6-cm hypoechogenic tumorous mass with sharp margins. A CT scan of the chest and abdomen showed an inhomogeneous round tumor of $73 \times 61 \mathrm{~mm}$ with sharp margins and with hypodense fatty components in combination with enhancing soft tissue. The mass was located mesenterially, ventrally of the musculus iliopsoas with surrounding enlarged lymph nodes (maximum diameter $12 \mathrm{~mm}$ ) (fig. 1). Differential diagnoses like teratoma, liposarcoma or IMT were suggested. An additional PET scan revealed paratracheal lymph nodes which were interpreted as reactive, and the known left paraumbilical mass with only capsular FDG uptake. Ultrasound-guided biopsies were taken which revealed spindle cell proliferation with a mixed inflammatory cell infiltrate, in which immunohistochemical analysis showed positivity for vimentin, pankeratin (not uniform), and focally smooth muscle actin and calponin, suggesting an IMT.

Given the clinical presentation and the pathological findings, it was decided to perform an explorative laparotomy with total resection of the tumor. Macroscopic inspection showed a tumor with a diameter of $10 \mathrm{~cm}$ with a smooth capsular outer surface (fig. 2). Due to locally aggressive growth, both a section of the colon and the jejunum had to be resected. Microscopy showed a mesenteric tumor comprising diffuse, not sharply delineated and unencapsulated spindle cell proliferation with lymph node involvement per continuitatem but without involvement of the colon or jejunum and without atypia. This spindle cell proliferation was accompanied by a cell-rich mixed inflammatory infiltrate with for instance many plasma cells, lymphocytes and eosinophilic granulocytes. The tumor contained centrally a large area of necrotic debris, maybe fat necrosis. Immunohistochemical analysis did not reveal signs of a specific spindle cell tumor, carcinoma or malignant lymphoma (fig. 3). The diagnosis was IMT (differential diagnosis: primary fat necrosis surrounded by a pseudocapsule of extensive reactive fibrosis with organization). The postoperative period was uncomplicated and the patient could be discharged from the hospital after 4 days.

\section{Discussion}

IMT, also known as inflammatory (myo)fibroblastic pseudotumor or inflammatory pseudotumor, is a rare benign neoplasm, often mistaken for malignancy or teratoma. The etiology of IMT is unknown, though it is suggested to occur secondary to infection like mycobacteria, Epstein-Barr virus, cytomegalovirus, actinomycetes, nocardia or an autoimmune reaction [1-5]. Furthermore it has been described after trauma or surgery, which was not the case in our patient [5-7]. IMT occurs at any age, though it is mainly described in children and young adults [7].

IMT most commonly involves the lung and orbit, though it has been described in nearly the entire body. Known cases of abdominal IMT include the liver, pancreas, mesentery, retroperitoneum, diaphragm, bladder, kidney, adrenal gland, esophagus, stomach, small 
Groenveld et al.: Abdominal Inflammatory Myofibroblastic Tumor

intestine, colon, appendix and Meckel's diverticulum $[8,9]$. Clinical presentation is variable according to the location of the tumor. These nonspecific symptoms can include fever, weight loss, abdominal pain or palpable abdominal mass with nonspecific laboratory findings such as iron deficiency anemia $[3,7,10,11]$. Like its clinical presentation, the appearance on CT scan is variable. After contrast enhancement, moderate or marked homogeneous or heterogeneous enhancement is seen in the solid part of the tumor [11, 12]. The mass has well-defined margins. Non-enhancement, calcification and fatty components have been described [12]. Because of the high uptake of tracer in IMT on PET scan, IMT is often difficult to differentiate from other neoplasms [11]. The differential diagnosis includes lymphoma, soft tissue sarcoma, metastatic disease and benign fibrous mesenteric tumor [13].

Histologically IMT is characterized by myofibroblastic spindle cells and inflammatory cells consisting of lymphocytes, histiocytes and eosinophils $[1,2,14,15]$. Staining for smooth muscle and vimentin are positive $[5,15,16]$. Furthermore IMT contains both B and T cells, in contradistinction to lymphomas, which contain only (clonal) B or T cells [17].

The treatment of abdominal IMT consists of complete surgical resection; moreover, this will confirm the diagnosis IMT by histological examination [18, 19]. Adjuvant therapies have been used without great success, though for local recurrences or inoperable tumors, radiotherapy and chemotherapy consisting of cisplatin, doxorubicin and methotrexate may be indicated $[1,15,18]$. Because of a significant local recurrence rate, long-term follow-up is mandatory [19].

\section{Disclosure Statement}

The authors declare no conflict of interest. There were no funding sources.

\section{References}

1 White JE, Chase CW, Kelley JE, et al: Inflammatory pseudotumor of the liver associated with extrahepatic infection. South Med J 1997;90:23-29.

2 Bell ND, Gavras JN, Donnell CA, et al: Renal inflammatory pseudotumor. South Med J 1998;91:1050-1053.

-3 Lo OS, Poon RT, Lam CM, et al: Inflammatory pseudotumor of the liver in association with a gastrointestinal stromal tumor: a case report. World J Gastroenterol 2004;10:1841-1843.

-4 Lado Lado FL, Páramo de Vega M, Torre Carballada JA, et al: Inflammatory pseudotumor of the spleen. Review and a new case report (in Spanish). An Med Interna 2004;21:279-282.

5 Dehner LP: The enigmatic inflammatory pseudotumours: the current state of our understanding, or misunderstanding. J Pathol 2000;192:277-279.

6 Wu JP, Yunis EJ, Fetterman G, et al: Inflammatory pseudo-tumours of the abdomen: plasma cell granulomas. J Clin Pathol 1973;26:943-948.

7 Sanders BM, West KW, Gingalewski C, et al: Inflammatory pseudotumor of the alimentary tract: clinical and surgical experience. J Pediatr Surg 2001;36:169-173.

-8 Erkan N, Yildirim M, Yilmaz C, et al: Inflammatory pseudo-tumour as an unusual cause of colonic obstruction: a case report. Acta Chir Belg 2004;104:462-464.

-9 Coffin CM, Watterson J, Priest JR, et al: Extrapulmonary inflammatory myofibroblastic tumor (inflammatory pseudotumor). A clinicopathologic and immunohistochemical study of 84 cases. Am J Surg Pathol 1995;19: 859-872.

10 Ladd AP, Grosfeld JL: Gastrointestinal tumors in children and adolescents. Semin Pediatr Surg 2006;15: 37-47.

11 Slavotinek JP, Bourne AJ, Sage MR, et al: Inflammatory pseudotumour of the pancreas in a child. Pediatr Radiol 2000;30:801-803.

12 Levy S, Sauvanet A, Diebold MD, et al: Spontaneous regression of an inflammatory pseudotumor of the liver presenting as an obstructing malignant biliary tumor. Gastrointest Endosc 2001;53:371-374. 
Groenveld et al.: Abdominal Inflammatory Myofibroblastic Tumor

13 Levy AD, Rimola J, Mehrotra AK, et al: From the archives of the AFIP: benign fibrous tumors and tumorlike lesions of the mesentery: radiologic-pathologic correlation. Radiographics 2006;26:245-264.

14 Chen CK, Jan CI, Tsai JS, et al: Inflammatory myofibroblastic tumor of the lung - a case report. J Cardiothorac Surg 2010;5:55.

15 Pungpapong S, Geiger XJ, Raimondo M: Inflammatory myofibroblastic tumor presenting as a pancreatic mass: a case report and review of the literature. JOP 2004;5:360-367.

16 Jensen JB, Langkilde NC, Lundbeck F, et al: Pseudosarcomatous fibromyxoid tumor of the prostate. Scand J Urol Nephrol 2003;37:85-87.

17 Narla LD, Newman B, Spottswood SS, et al: Inflammatory pseudotumor. Radiographics 2003;23:719-729.

18 Patnana M, Sevrukov AB, Elsayes KM, et al: Inflammatory pseudotumor: the great mimicker. AJR Am J Roentgenol 2012;198:W217-W227.

19 Cho MY, Min YK, Kim NR, et al: Fever of unknown origin as a presentation of gastric inflammatory myofibroblastic tumor in a two-year-old boy. J Korean Med Sci 2002;17:699-703.

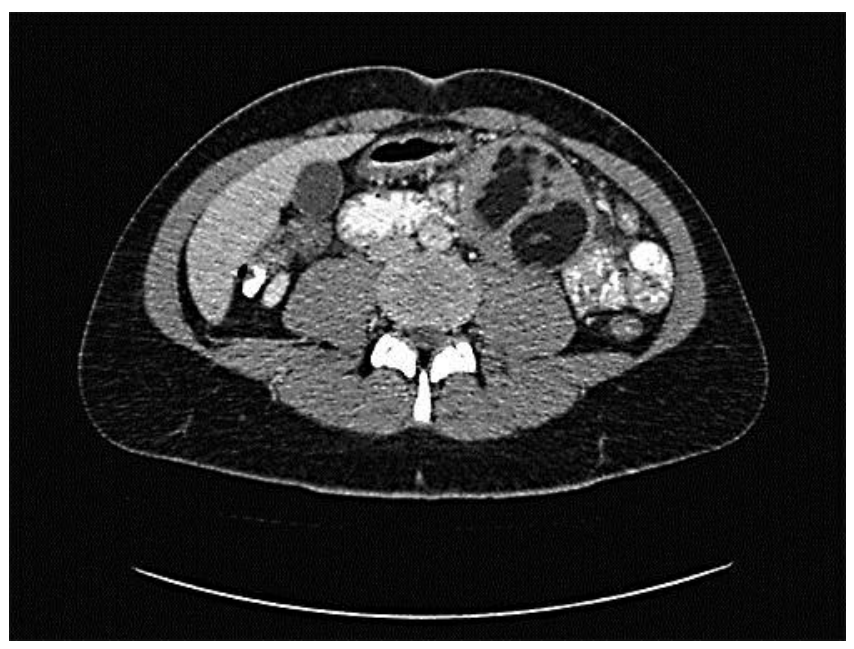

Fig. 1. Transversal section of the abdominal CT scan revealed an inhomogeneous round tumor of $73 \times$ $61 \mathrm{~mm}$ with sharp margins and with hypodense fatty components and enhancing soft tissue.

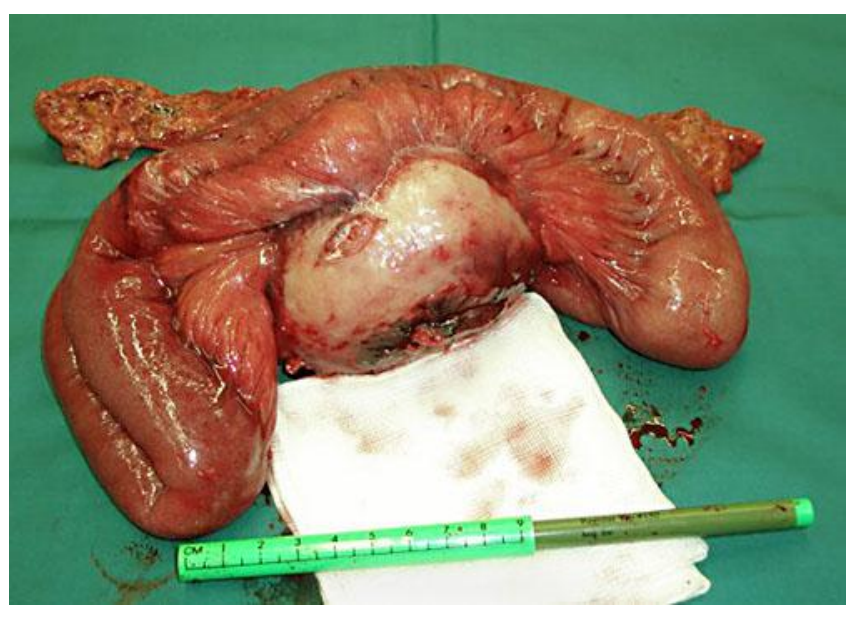

Fig. 2. Laparotomy showed a 10-cm-large tumor, which was completely resected. 
Groenveld et al.: Abdominal Inflammatory Myofibroblastic Tumor

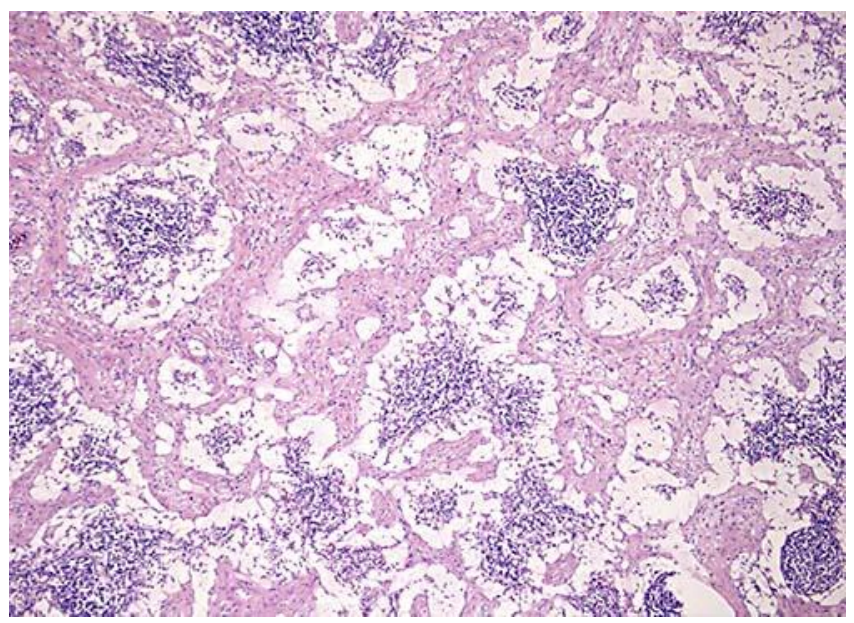

Fig. 3. Histological section with HE staining of the resected myofibroblastic tumor showing spindle cell proliferation, fibrotic lymph node involvement and central necrosis. Magnification $\times 5,000$. 